\title{
A Search for Resistance in Peas to Mycosphaerella pinodes
}

John M. Kraft, Supervisory Research Plant Pathologist, USDA/ARS/PWA, Prosser, WA 99350; Brendan Dunne, Plant Pathologist, Oak Park Agricultural Center, Carlow, Ireland; and David Goulden, Plant Breeder, and Stewart Armstrong, Agronomist, Crop and Food Research, Private Bag 4704, Christchurch, New Zealand

\begin{abstract}
Kraft, J. M., Dunne, B., Goulden, D., and Armstrong, S. 1998. A search for resistance in peas to Mycosphaerella pinodes. Plant Dis. 82:251-253.

In 1991, 1992, and 1994, 2,936 accessions of Pisum sativum from the USDA Plant Introduction collection were screened under field conditions for resistance to Mycosphaerella pinodes without replication due to seed supply. These trials were conducted at the Oak Park Research Station at Carlow, Ireland, where conditions are highly favorable for disease expression. In 1995, the 157 most resistant accessions were again screened at Carlow and at the Food and Crops Research Station at Gore, New Zealand, in replicated trials. At both locations, disease was severe and ranged from 20 to $100 \%$ foliar blight. Five accessions were as resistant as the commercial cultivar Radley at both locations: PI 142441, PI 142442, PI 381132, PI 404221, and PI 413691. No accessions were more resistant than the cultivar Radley.
\end{abstract}

Additional keywords: foliar disease

Foliar diseases, caused primarily by $M y$ cosphaerella pinodes (Berk. \& Bloxam.) and to a lesser extent by Ascochyta pisi Lib. are a serious economic threat to both protein (combining) and processing (canning and freezing) peas (Pisum sativum L.) wherever pea crops are grown. This is particularly true in the temperate zones of Europe, North America, Australia, and New Zealand $(6,7,10,11)$. Leaf infection by $M$. pinodes results in small brown to black lesions, which remain small under dry conditions. However, with moist conditions the lesions enlarge. Affected leaves can be killed and stem lesions can enlarge and coalesce to completely girdle stems, giving the entire lower plant a blue-black appearance. Moist conditions are necessary for infection and plant-to-plant spread. Plants are susceptible at any age, but mature leaves are most susceptible (2).

Currently, no genetic resistance/tolerance to $M$. pinodes has been developed in commercial pea cultivars. No single gene for a high level of resistance to $M$. pinodes

Corresponding author: John M. Kraft

E-mail: jkraft@tricity.wsu.edu

Names are necessary to report factually on available data; however, the USDA neither guarantees nor warrants the standard of the product, and the use of the name by USDA implies no approval of the product to the exclusion of others that may also be suitable.

Accepted for publication 29 October 1997.

Publication no. D-1997-1219-03R

This article is in the public domain and not copyrightable. It may be freely reprinted with customary crediting of the source. The American Phytopathological Society, 1998. has been found, despite extensive searches of the available gene pool. The possibility of physiological specialization within $M$. pinodes makes it even more difficult to develop resistant cultivars. Clulow et al. (4) reported that numerous pathotypes of $M$. pinodes exist, and Nasir and Hoppe (8) divided 50 single conidium-derived isolates into 6 pathotypes using 15 pea cultivars. Consequently, it may be necessary to incorporate several resistance genes for a cultivar to exhibit field resistance to $M$. pinodes. Evaluations of cultivar reactions to $M$. pinodes can be misleading because reliable tests are difficult to design $(2,9)$. Peas become more susceptible as they mature and should be evaluated for disease reaction at the same physiological age. Whether disease screening occurs in the field or under controlled conditions, infection should discriminate between very susceptible and very resistant classes. After disease resistant plants have been identified, it is important to determine whether this resistance is effective against the prevalent pathotypes of $M$. pinodes. Clulow (3) reported that several wild accessions of Pisum sativum were resistant in a controlled environment. Ali et al. (1) reported that seedling resistance to $M$. pinodes is no indication of adult resistance.

The Oak Park Research Center near Carlow, Ireland, is in the center of an intensive arable farming area about $80 \mathrm{~km}$ southwest of Dublin. Foliar blight, caused by $M$. pinodes, is a serious yield- and quality-limiting factor. Consequently, farmers are reluctant to grow peas and acreages remain below 2,000 ha in the Irish Republic. On the South Island of New Zealand near Gore, combining peas are used as a rotation crop with cereals, pota- toes, and brassica crops. Rainfall varies from 56 to $109 \mathrm{~mm}$ during the growing season from October to February. The average number of days with more than 1 $\mathrm{mm}$ of rainfall during the growing season varies from 12 in September to 9 in February. Maximum and minimum temperatures for those months vary from 21 to $28^{\circ} \mathrm{C}$ and from 0 to $4^{\circ} \mathrm{C}$, respectively. With high relative humidity during this time, conditions for M. pinodes are ideal and blight is a yield-limiting factor in this area.

The purpose of this research was to evaluate the available United States Department of Agriculture (USDA) Plant Introduction pea collection for resistance to $M$. pinodes under field conditions in Ireland and New Zealand.

\section{MATERIALS AND METHODS}

Trials at Carlow, Ireland. The available USDA Plant Introduction (PI) collection of peas $(2,936$ accessions) was evaluated at the Oak Park Research Center, Carlow, Ireland, where infection by $M$. pinodes occurs naturally and where confounding diseases such as root rot, wilt, and virus diseases are not chronic. Each pea line was planted in a $1.4-$ by $1.2-\mathrm{m}$ plot using an Oyjord seed drill. The space between plots was $0.4 \mathrm{~m}$. The control consisted of the susceptible commercial cultivar Solara planted three times throughout the plot area.

In 1991, $245 \mathrm{~kg} / \mathrm{ha}$ of 0:7:30 (N, P, K) was broadcast and the herbicide Opogard (terbuthylazine and terbutryne 150:350 g/liter a.i.) was applied at 2.5 liters/ha. The insecticide Ammo (cypermethrin 100 g/liter a.i.) was applied at $250 \mathrm{ml} / \mathrm{ha}$ on 21 May. The trial was planted on 24 April and selected plots were harvested on 3 September. In 1992, $300 \mathrm{~kg} / \mathrm{ha}$ of 0:10:20 (N, $\mathrm{P}, \mathrm{K})$ was broadcast and Opogard applied at 2.0 liters/ha. The insecticide Asana (esfenvalerate $25 \mathrm{~g} /$ liter a.i.) was applied at $500 \mathrm{ml} / \mathrm{ha}$ on 20 May. The trial was sown on 4 May and harvested on 18 September. In 1994, $300 \mathrm{~kg} / \mathrm{ha}$ of 0:10:20 (N, P, K) was broadcast and the herbicide Basagran (sodium salt of bentazon $477 \mathrm{~g} /$ liter a.i.) and Asana were applied at 1.5 liters and $500 \mathrm{ml} / \mathrm{ha}$, respectively. The trial was sown on 13 April and harvested on 21 September. In 1995, $245 \mathrm{~kg} / \mathrm{ha}$ of 0:7:30 (N, P, K) was broadcast and Opogard was applied at 2.0 liters/ha. The insecticide Dimethoate (400 g/liter a.i.) was applied at $850 \mathrm{ml} / \mathrm{ha}$ on 2 June. The trial was sown on 30 March and harvested on 8 August. 
In 1991, 1992, and 1994, only one plot of 50 seeds was planted per accession due to seed limitations. In 1991, 1992, and 1994, 1,290, 1,000, and 646 lines were screened, respectively. In 1995, 157 lines, scored as resistant the previous years (disease rating from 0 to $40 \%$ ), which were mature at the last rating and possessed the recessive $a$ gene for lack of anthocyanin pigmentation, were planted with six replications. The trial was planted in a randomized complete block design and data analyzed for least significant differences. The resistant, combining pea "Radley" served as the control and was also replicated six times.

To ensure uniform infection, plots were inoculated each year with an isolate of $M$. pinodes obtained from seed supplied by Dr. Anthony Biddle (Processors and Growers Research Organization, Peterborough, England). Isolation was according to the method of Hewett (5) and was confirmed by Dr. Walter Kaiser, USDA-Agriculture Research Service, Pullman, Washington. To obtain cultures to inoculate plots in the following years, $M$. pinodes was re-isolated from seed of the previous year's trial. Inoculum was increased on autoclaved sugar beet seed, supplemented with a $2 \%$ glucose solution, and incubated 7 days in a dark cabinet maintained at 18 to $20^{\circ} \mathrm{C}$. Sufficient inoculum was prepared to inoculate each plot with $50 \mathrm{~g}$ fresh weight. Inoculum was distributed evenly within each plot when the plant canopy completely covered the soil surface. Plots were inoculated on 6 June 1991, 15 June 1992, 20 June 1994, and 14 June 1995. Seed of the pea cultivar Solara, known to be infected with $M$. pinodes, was planted in the borders and alleys to increase the probability of infection.

Each line was rated for blight severity using a 0 to $100 \%$ scale, where $0=$ no disease present and $100=$ all plants within plot severely infected, lesions coalesced, and vines blue-black in color. Total lesion development within each plot was estimated. Disease ratings were initiated when the majority of the plots were at least in the flat-pod stage. When each plot was rated for disease severity, a maturity rating was also given based on a 0 to 5 scale, where 0 = no flowers or pods, $1=$ flowering, $2=$ some flat pods on several bloom nodes, $3=$ some mature pods at first bloom nodes, flat pods at top of plants, $4=$ mature pods on all but top nodes, and $5=$ fully mature pods on all nodes. Each plot was rated at least twice during the growing season. The comparisons of resistance were based on the most severe of the two or more ratings for each line.

Trials at Gore, New Zealand. In 1995, the same 157 lines that were planted in a replicated trial at Carlow, Ireland, were also planted in a replicated trial at the Crop and Food Research Station at Gore, New Zealand. Soilborne inoculum of $M$. pinodes was plentiful at this site due to previous studies.

Plots were sown with a cone seeder with 50 seeds/row of each plot replicated three times. The herbicide tertuthylazine was applied preemergence at 2 liters/ha, and haloxyfop and metribuzin were applied as a post-emergence treatment at 1.25 liters and $500 \mathrm{~g} / \mathrm{ha}$ rate, respectively. Seed of cv. Rovar, infected with $M$. pinodes, was planted in the alleyways to serve as primary inoculum. Natural infection from soil and infected border rows served as primary inoculum.

Disease severity ratings were taken when all lines were at least in flat-pod to full-pod maturity. The same disease severity index used in Ireland was used here, where $0=$ no disease and $100=$ entire plot canopy was severely infected. Also, maturity ratings were taken for each plot scored for disease severity using the 0 to 5 scale described previously.

Isolation of $M$. pinodes from seed. Seed from selected field plots at Carlow was plated on Difco potato dextrose agar to determine the amount of $M$. pinodes present. Two hundred seeds from each plot were surface disinfested for $10 \mathrm{~min}$ with $1 \% \mathrm{NaOCl}$, rinsed for $30 \mathrm{~s}$ in sterile water, and plated (5). The plates were incubated in the dark at $20 \pm 1^{\circ} \mathrm{C}$ for 3 days and then under constant UV light for 5 days at $18 \pm$ $2{ }^{\circ} \mathrm{C}$ to stimulate pycnidial development.

\section{RESULTS}

The available collection of PI accessions of peas was screened for resistance to $M$. pinodes at the Oak Park Research Center, Carlow, Ireland. Of the 2,936 accessions screened with one replication per accession during 1991, 1992, and 1994, 73 were rated $40 \%$ or less for disease severity. In 1995, these same 73 lines, plus 84 other lines rated at 40 to $50 \%$, were again screened in a replicated trial. Seventeen of these lines were found resistant. The results of all 4 years are given in Table 1 . Only those lines which were rated as fully mature (with a maturity rating of 4 or 5)

Table 1. Distribution of resistance to $M y$ cosphaerella pinodes among Plant Introduction (PI) pea accessions screened at Carlow, Ireland, 1991 to 1995

\begin{tabular}{ccc}
\hline & \multicolumn{2}{c}{ Number of accessions } \\
\cline { 2 - 3 } Year & Tested & Resistant at maturity \\
\hline 1991 & 1,290 & 26 \\
1992 & 1,000 & 23 \\
1994 & 646 & 24 \\
1995 & 157 & 17 \\
\hline
\end{tabular}

a PI accessions that were scored $\leq 40 \%$ disease resistant and with a maturity rating of 4 or 5 , where $0=$ no pods or flowering, $1=$ flowering, 2 = some flat pods on several bloom nodes, $3=$ some mature pods at first bloom nodes and flat pods at top of plants, $4=$ mature pods on all but top nodes, and $5=$ all pods mature. and with a $40 \%$ or lower rating for disease severity were classified as resistant. In 1991, the range in disease severity ratings among lines varied from 20 to $95 \%$. In the resistant classification, the range in disease severity was from 20 to $40 \%$ and the percent seed infection with $M$. pinodes varied from 4 to $55 \%$. PI accessions 206871 and 206840, which scored $40 \%$ for disease severity and 4 for maturity, exhibited a low $4 \%$ seed infection. PI accessions 244119 and 244259 were also classified as resistant and had seed infection rates of $10 \%$.

Table 2. Best lines from Mycosphaerella pinodes screening trials at Carlow, Ireland, and Gore, New Zealand, in 1995

\begin{tabular}{|c|c|}
\hline Location, line & Disease rating \\
\hline \multicolumn{2}{|l|}{ Carlow, Ireland } \\
\hline 142441 & 18 \\
\hline 142442 & 17 \\
\hline 261622 & 23 \\
\hline 285746 & 22 \\
\hline 347407 & 23 \\
\hline 356835 & 23 \\
\hline 356843 & 24 \\
\hline 356853 & 23 \\
\hline 356877 & 21 \\
\hline 356878 & 21 \\
\hline 356889 & 23 \\
\hline 356890 & 24 \\
\hline 356892 & 20 \\
\hline 356929 & 22 \\
\hline 356932 & 20 \\
\hline 356937 & 24 \\
\hline 356939 & 23 \\
\hline 356942 & 24 \\
\hline 356953 & 21 \\
\hline 356954 & 23 \\
\hline 381132 & 23 \\
\hline 404220 & 21 \\
\hline 404221 & 21 \\
\hline 413691 & 24 \\
\hline 512082 & 24 \\
\hline Radley & 23 \\
\hline $\mathrm{LSD}^{\mathrm{a}}=6.33$ & \\
\hline \multicolumn{2}{|c|}{ Gore, New Zealand } \\
\hline 142441 & 32 \\
\hline 142442 & 28 \\
\hline 210561 & 32 \\
\hline 244187 & 33 \\
\hline 275824 & 32 \\
\hline 279824 & 20 \\
\hline 279825 & 28 \\
\hline 280617 & 32 \\
\hline 285710 & 28 \\
\hline 285736 & 32 \\
\hline 288026 & 27 \\
\hline 288030 & 33 \\
\hline 314794 & 33 \\
\hline 319374 & 33 \\
\hline 356914 & 30 \\
\hline 356919 & 33 \\
\hline 379612 & 32 \\
\hline 381132 & 30 \\
\hline 404221 & 27 \\
\hline 411143 & 33 \\
\hline 413690 & 33 \\
\hline 413691 & 27 \\
\hline 413698 & 28 \\
\hline Radley & 25 \\
\hline $\mathrm{LSD}=11.62$ & \\
\hline
\end{tabular}

${ }^{a}$ Least significant difference, $P=0.05$. 
In 1992, 1,000 PI accessions were evaluated at Carlow and each plot was scored at least three times for disease severity and maturity. There were 23 lines rated with $40 \%$ or lower disease severity and a maturity rating of 4 or 5 .

In 1994, the remaining 652 available PI accessions were evaluated. Twenty-one lines were rated with $40 \%$ or lower disease severity and a 4 to 5 maturity rating.

In 1995, 157 PI accessions were again screened in six replications/line in a completely randomized design. The most resistant lines, those which had a foliar disease rating of 17 to $24 \%$, are listed in Table 2. The dry pea Radley exhibited a disease rating of 23. Also in 1995, these same 157 lines were evaluated at Gore, New Zealand. The most resistant lines at Gore are also listed in Table 2. Radley again was planted as the commercial control. PI accessions 142441 142442, 381132, 404221, and 413691 were resistant at both locations.

\section{DISCUSSION}

Field evaluation of the available PI collection of peas at Carlow, Ireland, and Gore, New Zealand, revealed that a high level of resistance to $M$. pinodes did not exist in this collection. No line was significantly more resistant than the commercial cultivar Radley. Unfortunately, as in previous, similar studies, immunity or even a high level of resistance was not detected $(1,3)$. Of 157 lines evaluated in Ireland and New Zealand, only 5 were as resistant as Radley at both locations. This is an indi- cation of the presence of different biotypes or strains of this pathogen and that resistance to all these strains is not prevalent in the PI collection.

Foliar, stem, and pod blight caused by $M$. pinodes is reported to worsen as the plant matures. Consequently, seedling evaluation for resistance does not address this fact and can lead to erroneous results. Previous research has found no correlation between foot rot and foliar disease scores $(8,9,11)$. Consequently, no followup studies were conducted during this study to determine if those lines found resistant to $M$. pinodes under field conditions were also resistant to foot rot. $\mathrm{Na}$ sir and Hoppe (8) found that the pea cultivars Danto and Bohatyr were moderately resistant to foliar blight. They concluded that the lack of correlation between foliar blight and foot rot resistance and the high level of virulence differences among isolates of $M$. pinodes was not conducive to rapid development of resistant cultivars.

Because neither highly resistant cultivars nor PI accessions exist, breeding for resistance to this disease will most likely depend on recurrent selection to compile minor genes. Those 5 PI accessions found to be as resistant as Radley at both Carlow, Ireland, and Gore, New Zealand, could be intercrossed to compile minor genes for resistance to $M$. pinodes. This process takes many years and has been ongoing since the early 1970s (1). Perhaps genetic engineering can also be used to augment the low level of resistance currently available.

\section{LITERATURE CITED}

1. Ali, S. M., Nitsche, L. F., Dube, A. J., Krause, M. R., and Cameron, B. 1978. Selection off pea lines for resistance to pathotypes of Ascochyta pinodes, Ascochyta pisi, and Phoma medicaginis var. pinodella. Aust. J. Agric. Res. 29:841-849.

2. Bretag, T. 1991. Epidemiology and control of Ascochyta blight of field peas. Ph.D. Thesis. La Trobe University, Victoria, Australia.

3. Clulow, S. A. 1989. The resistance of Pisum to Mycosphaerella pinodes (Berk. \& Blox. Vestergr. Ph.D. thesis. University of East Anglia, United Kingdom.

4. Clulow, S. A., Matthews, P., and Lewis, B. G. 1991. A pathotype classification of $\mathrm{Myco}$ sphaerella pinodes. J. Phytopathol. 131:322:332.

5. Hewett, P. D. 1966. Ascochyta fabae Speg. on tick bean seed. Plant Pathol. 15:161-163.

6. Lawyer, A. S. 1984. Diseases caused by Ascochyta. Pages 11-13 in: Compendium of Pea Diseases. D. J. Hagedorn, ed. American Phytopathological Society, St. Paul, MN.

7. McKenzie, D. L., and Morrall, R. A. 1973. Diseases of three specialty legume crops in Saskatchewan in 1972. Field pea, lentil, and faba bean. Can. Plant Dis. Surv. 53:187-190.

8. Nasir, M., and Hoppe, H. H. 1991. Studies on pathotype differentiation with Mycosphaer ella pinodes (Berk. \& Bloxam) Vestergren, a component of the Ascochyta-disease-complex of peas (Pisum sativum L.). J. Plant Dis. Prot. 98:619-626.

9. Sakar, D., Muehlbauer, F. J., and Kraft, J. M. 1982. Techniques for screening peas for resistance to Phoma medicaginis var. pinodella. Crop Sci. 22:988-992.

10. Wallen, V. R. 1974. Influence of three Ascochyta diseases of peas on plant development and yield. Can. Plant Dis. Surv. 54:86-90.

11. Xue, A. G, Warkentin, T. D., Greeniaus, M. T., and Zimmer, R. C. 1996. Genotypic variability in seedborne infection of field pea by Mycosphaerella pinodes and its relation to foliar disease severity. Can. J. Plant Pathol. 18:370-374. 